$1-1-2001$

\title{
Staying Alive: Executive Clemency, Equal Protection, and the Politics of Gender in Women's Capital Cases
}

Elizabeth Rapaport

University of New Mexico - School of Law

Follow this and additional works at: https://digitalrepository.unm.edu/law_facultyscholarship

Part of the Law and Gender Commons

\section{Recommended Citation}

Elizabeth Rapaport, Staying Alive: Executive Clemency, Equal Protection, and the Politics of Gender in Women's Capital Cases, 4 Buffalo Criminal Law Review 967 (2001).

Available at: https://digitalrepository.unm.edu/law_facultyscholarship/39

This Article is brought to you for free and open access by the UNM School of Law at UNM Digital Repository. It has been accepted for inclusion in Faculty Scholarship by an authorized administrator of UNM Digital Repository. For more information, please contact amywinter@unm.edu, Isloane@salud.unm.edu, sarahrk@unm.edu.

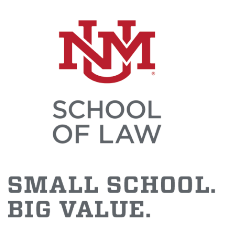

BIG VALUE. 


\title{
Staying Alive: Executive Clemency, Equal Protection, and the Politics of Gender in Women's Capital Cases
}

\author{
Elizabeth Rapaport*
}

Clemency in capital cases, once routine, has become a rare event in the contemporary death penalty era. Although the majority of state executives enjoy the traditional plenary power in clemency cases, very few have used it liberally. As use of the power has declined, the political risks of commutation have intensified. The contemporary governor contemplating a grant of clemency can anticipate considerable scrutiny of his or her use of the power. When a governor confronts the duty of deciding whether to allow a woman capital prisoner to be executed, he or she is additionally forced to navigate the politics of gender in the new age of formal sexual equality.

The recent past has demonstrated that there is little for a governor to fear by way of adverse political consequences for permitting the execution of women. The execution of Karla Faye Tucker in Texas in 1998, was the first execution of a woman after a hiatus of fourteen years, and the first since the era of formal equality has been well established. It was surrounded by intense speculation about whether then Governor George W. Bush would be harmed politically by permitting the execution of a woman. Since the Tucker execution, four women have been executed with ever diminishing media interest in the executions and the impact on the careers of presiding executives. Governors have reason to be reassured that they will not be whipsawed should they allow the execution of a woman, caught between demands for even-handed gender justice and countervailing strong public sentiment for protective tenderness.

\footnotetext{
* Professor of Law, University of New Mexico. I thank Kalman P. Bland, James W. Ellis, Lynne Henderson, and Michael L. Radelet. Lisa R. Dials provided invaluable research assistance, for which I thank her.
} 
Yet death row women have been more successful than men in garnering executive clemency. The few governors who have made these grants -in almost in all cases at the end of their careers in elected office-have offered little or no public explanation for their actions. Grants of clemency are vulnerable to the charge that the executive has failed to treat like cases alike and are at least morally unjust because equally worthy inmates have been denied. Grants to women may appear to violate equal protection by according special treatment by reason of gender.

In this Article, I will review the matrix in which executive decisions in women's capital clemency cases are made, a matrix supplied by modern equal protection law, the nature and scope of the clemency power, gender politics, and contemporary death row. I will then conduct two thought experiments. Each invented case tests the relevance of gender in legally and politically acceptable contemporary clemency decisions. The goal is to understand the politics and law of granting or denying that very rare boon-commutation of sentence-to a female death row prisoner. The exercise offers support for two conclusions. In the age of formal equality, women cannot be granted clemency simply because they are women. The rhetoric of chivalry is untenable for the contemporary executive. A governor who is courageous and rhetorically skillful, however, can sometimes successfully defend the commutation of the death sentence of a woman as a proper use of the power to grant mercy, done for her sake, the class she exemplifies, the conscience of the governor, and the public.

\section{EQUAL PROTECTION AND THE CONTEMPORARY ExECUTIVE: CONSTITUTIONAL PREROGATIVE AND POLITICAL REALITY}

The power to grant clemency, to remit or delay punishment, and pardon offenses is vested by the Federal 
Constitution in the President. ${ }^{1}$ State constitutions provide a variety of clemency procedures, but the majority vest the governor with sole clemency authority or final authority to act upon the recommendations of a clemency board. ${ }^{2}$ The clemency power is plenary, free of legislative control ${ }^{3}$ and "rarely if ever" subject to review by courts. ${ }^{5}$ According to this dominant view, the executive may, for all legislators or courts can do about it, grant or deny clemency for a good reason, a bad reason, or no reason at all. ${ }^{6}$ The only remedy for bad judgment or venal conduct is impeachment. ${ }^{7}$ The clemency power, often described by its critics as an unsavory relic of monarchical government, ${ }^{8}$ escaped the due process and equal protection revolutions of the latter half of the twentieth century.

In 1998, the United States Supreme Court for the first time held the clemency power to be subject to judicial

1. See U.S. Const. art. II, $\S 2$.

2. The most recent study of executive clemency procedures in the 50 states and at the federal level is Clifford Dorne \& Kenneth Gewerth, Mercy in a Climate of Retributive Justice: Interpretations from a National Survey of Executive Clemency Procedures, 25 New Eng. J. on Crim. \& Civ. Confinement 413 (1999); see also Nat'l Governors' Ass'n Ctr. For Pol'y Res., Guide to Executive Clemency Among the American States (1988) (containing information about the practice of clemency and clemency procedures); Nat'l Ctr. For the State Courts, Clemency: Legal Authority, Procedure, and Structure (Samuel P. Stafford ed., 1977) (surveying clemency procedures).

Typically, where a clemency board is employed, the governor appoints its members. In some states clemency requires the approval of both the board and the governor while in five states the power is vested in a board. See Dorne \& Gewerth, supra at 427-29.

3. Schick v. Reed, 419 U.S. 256, 267 (1974).

4. Conn. Bd. of Pardons v. Dumschat, 452 U.S. 458, 464 (1981).

5. See Daniel T. Kobil, The Quality of Mercy: Resting the Pardoning Power from the King, 69 Tex. L. Rev. 569, 589-620 (1991); William Duker, The President's Power to Pardon: A Constitutional History, 18 Wm. \& Mary L. Rev. 475 (1977).

6. Ex parte Grossman, 267 U.S. 87, 120-21 (1925).

7. Id. at 121 . In a few states, courts void pardons granted mistakenly or fraudulently. See also Dorne \& Gewerth, supra note 2, at 459 .

8. For a defense of discretion in clemency determination,s see Kathleen Dean Moore, Pardons: Justice, Mercy and the Public Interest 1-86 (1989); Duker, supra note 5; Elizabeth Rapaport, Retribution and Redemption in the Operation of Executive Clemency, 74 Chi.-Kent L. Rev. 1501 (2000) [hereinafter Rapaport, Retribution and Redemption]. 
review. In Ohio Adult Parole Authority v. Woodard,$^{9}$ a majority of the Supreme Court held that the Fourteenth Amendment requires minimal due process be accorded capital inmates in clemency proceedings. ${ }^{10}$ Woodard feeds several intertwined strands of reform pressure aimed at the traditional discretionary power enjoyed by the federal executive and the majority of governors. The Woodard opinion refocuses our attention on the clash between the plenary discretion of the clemency authority and modern constitutional and bureaucratic norms. These norms demand that government actors employ regular and fair proceedings and make decisions for good reasons, neither arbitrarily nor under the sway of bias. Woodard, therefore, offers some encouragement to those who hope that, once the nose of the due process camel is under the clemency tent, greater protection will come in time.- Woodard inspires speculation about the applicability of equal protection law to clemency decisions. And it encourages inmates to seek enforcement of due process and equal protection claims in the courts. ${ }^{11}$

Five justices in Woodard were persuaded that the death-is-different doctrines upon which the Court has relied in developing special procedural requirements for capital cases had relevance in the clemency arena as well. The Court had previously established that the liberty interest in freedom from confinement protected by the Due Process Clause of the Fourteenth Amendment is "extinguished" ${ }^{2}$ by lawful conviction and sentence and that therefore a petition for clemency "is simply a unilateral hope."13 But in Woodard a majority held that a protected

9. 523 U.S. 272 (1998) (Rehnquist, C.J., Scalia, J., Kennedy, J., Thomas, J. (plurality opinion)); (O'Connor, J., Souter, J., Ginsburg, J., Breyer; J, concurring.); (Stevens, J., dissenting ).

10. Ohio Adult Parole Auth. v. Woodard requires that if clemency is available, minimum due process must be observed; it does not require that clemency be available. Id. at 292 (Stevens, J., dissenting), All death penalty states offer such proceedings. See id, at 295 n. 4 .

11. See, e.g., Wigglesworth v. Mauldin, 990 P.2d 26 (Ariz. 1999):

12. Conn. Bd. of Pardons v. Dumschat, 452 U.S. 458,464 (1981).

13. Id. at 465. But see Greenholtz v. Inmates of Neb. Penal \& Corr. Complex, 
interest in life, if not liberty, survives until execution in capital cases. Thus, "some minimal procedural safeguards apply to clemency proceedings." Justice O'Connor wrote in her concurrence:

Judicial intervention might, for example, be warranted in the face of a scheme whereby a state official flipped a coin to determine whether to grant clemency, or in a case where the State arbitrarily denied a prisoner any access to its clemency process. ${ }^{15}$

Justice Stevens focused not on the extent of process due in capital cases, as did Justice O'Connor, but on the kinds of alleged violations of due process courts should review. Where procedures are "infected by bribery, personal animosity, or deliberate fabrication of false evidence," cases ought to be subject to review. ${ }^{16}$ And he alone discussed the reach of the Equal Protection Clause, commenting that "no one would contend that a governor could ignore the commands of the Equal Protection Clause and use race, religion or political affiliation as a standard for granting and denying clemency."17

Stevens opinion suggests the innovation a majority embrace in Woodard may be more far-reaching, at least in capital cases, than $\mathrm{O}^{\prime}$ Connor acknowledges. It is difficult to see where the principled line would be drawn between the arbitrariness of coin flips or denial of access to process that O'Connor would subject to judicial intervention and denial

442 U.S. 1 (1979) (holding that the due process clause does apply to statutorily mandated criteria for commutation where they exist).

14. Woodard, 523 U.S. at 274. Five justices made a court for the holding that minimal due process protection must be accorded the capital prisoner seeking clemency. Justice $O^{\prime}$ Connor was joined by three justices in concurring with the plurality that no further process was due Woodard, who had been accorded notice and opportunity to be heard. But the concurring justices agreed with Justice Stevens, the lone dissenter, that a capital clemency petitioner's residual life interest, an interest which survives condemnation, is protected by minimal due process safeguards in clemency proceedings.

15. Id. at 289 .

16. Id. at $290-91$.

17. Id. at 292. 
of fair process or equal protection due to race or gender prejudice.

The argument relied upon by five justices to distinguish capital and non-capital clemency cases with regard to due process protection is not very convincing. The argument turns on the distinction between constitutional protection of interests in life and liberty. While the protected interest in liberty does not survive lawful confinement, the interest in life survives condemnation for as long as the inmate draws breath. ${ }^{18}$ For Justice Stevens, whose position is endorsed by the four concurring justices, ${ }^{19}$ it is "obviously" the case that a "a living person has a constitutionally protected interest in life." Chief Justice Rehnquist, writing for the plurality, is in agreement that there is a residual surviving life interest and apparently that some protection is due that interest, for example, in resisting summary execution by guards. ${ }^{22}$ The Chief Justice disagrees with five colleagues about whether this residual interest requires due process protection in clemency proceedings: Stevens relies on the death-is-different doctrines ${ }^{23}$ that have supported special due process protections in capital cases to respond to Rehnquist's challenge. Stevens invokes the greater severity and finality of the death penalty. ${ }^{24}$ Why the life of an inmate may be drained away by inches, decade after decade, without some modicum of constitutional protection in clemency proceedings but not taken all at once by

18. The distinction is somewhat overdrawn. The Supreme Court has held that absent state created rights to parole or commutation, there is no surviving federal constitutional right to pursue release. However, inmates do retain some protected liberty, i.e., from being forced to submit to psychotropic drugs or being made to enduxe punishment beyond that imposed by sentence. See Phillip John Strach, Ohio Adult Parole Authority v. Woodard: Breathing New "Life" into an Old Fourteenth Amendment Controversy, 77 N.C. L. Rev. 891 (1999).

19. See Woodard, 523 U.S. at 288-89 (O'Connor, J., concurring); id. at 293-94 (Stevens, J., dissenting).

20. Id. at 291 .

21. Id.

22. Id. at 273.

23. Gardner v. Florida, 430 U.S. 349, 357-58 (1977).

24. Woodard, 523 U.S. at 293-95. 
execution is not explained. ${ }^{25}$ The formalistic distinction between liberty and life interests in Woodard obscures the issues before the Court. The Court was asked to decide what, if anything, ought to be done to resolve the tensions between the policy, hallowed by the Founders, ${ }^{26}$ of insulating clemency decisions from accountability to the other two branches of government and modern due process jurisprudence.

Whether or not Woodard is ever extended so that due process and equal protection rights are more amply reviewable in clemency proceedings, the contemporary executive cannot afford to ignore due process and equal protection values in clemency determinations, unless he or she has no interest in remaining in public office. While arguably the very nature of clemency is that some receive a boon to which they are not entitled, while others, similarly situated, are denied, so ingrained are contrary expectations about government actions of any kind that the cry will be heard, "It's not fair."2?

Contemporary presidents and governors in the majority of states enjoy much the same clemency authority that their predecessors enjoyed 50 or 100 years ago; but the legal and political climate in which those decisions are made has been transformed. Fifty years ago, a governor's discretion in clemency was not starkly different from the discretion of sentencing judges and parole authorities in other phases of the penal regime, but the discretion of

25. Stevens was himself in dissent in Conn. Bd. of Pardons v. Dumschat, believing that it was "self-evident" that a protected liberty interest survived lawful incarceration. See 452 U.S. 458 (Stevens, J., concurring in part, dissenting in part). The relative severity of long term incarceration and execution is a subject about which reasonable minds can disagree. Both are at the highest reaches of the severity scale. The losses in either case are catastrophic and defy any thought of adequate redress or compensation.

26. Woodard, 523 U.S. at 284-85.

27. So, for example, said Ginger Whitacre, adding "[i]t's supposed to be equal." Kurt Eichenwald \& Michael Moss, Rising Number Sought Pardons in Last 2 Years, N.Y. Times, Jan. 29, 2001, at A1. She was referring to the failure of her husband Mark to obtain commutation of a sentence for fraud and price-fixing from President Clinton. Whitacre was complaining about a particular type of unfairness, "[a]nd it comes down to whether you have money or not!" Id. 
judges and parole authorities has since been severely constrained by the revolution in criminal justice philosophy and policy that overtook the criminal justice system a quarter century ago. ${ }^{28}$ That revolution had complex sources, including the powerful resurgence of a punitive ethos that overwhelmed the prior longstanding adherence to rehabilitation as the ideal of the penal system.

One driving motivation of the reform effort was to eliminate discrimination in treatment that disfavored racial minorities by curbing the discretion of sentencing judges and parole authorities. ${ }^{29}$ Women also suffered disproportionate lengths of incarceration as a result of prevailing stereotypes about gender differences. ${ }^{30}$ Such notions as that women were more amenable to rehabilitation gave rise to statutes which imposed longer incarceration to capitalize on this docility or teachability; such statutory disparate treatment was held to violate equal protection in the late 1960's and 1970's. ${ }^{31}$ Perhaps the symbol and best-known example of discriminatory sentencing was the virtual reservation of capital rape for cases involving black defendants and white victims in the South. ${ }^{32}$ The discriminatory imposition of capital punishment by juries in capital cases was also a target of reform and led to the structured discretion approach fabricated in post-Furman death penalty law. ${ }^{33}$ Broad discretionary authority has survived the reform impulse only in the office of the prosecutor and in the plenary power of executives in clemency decisions; unlike prosecutors, the discretion of executives in clemency is constitutionally

28. See generally Michael H. Tonry, Sentencing Matters (1996); Rapaport, Retribution and Redemption, supra note 8, at 1507-08.

29. See Michael H. Tonry, Malign Neglect: Race, Crime, and Punishment in America (1995).

30. See Marianne Popiel, Note, Sentencing Women: Equal Protection in the Context of Discretionary Decisionmaking, 6 Women's Rts. L. Rep. 85 (1979-80).

31. Id. at 92.

32. See William Bowers, Legal Homicide 59-60 (1984).

33. See generally David Baldus et al., Equal Justice and the Death Penalty: A Legal and Empirical Analysis (1990) (assessing the success of the reform program). 
insulated from legislative reform and judicial review.

While the executive may be almost as insulated from judicial review or legislative control today as 50 or 100 years ago, the political climate has changed dramatically. In addition to the established habit of suspicion towards discretion in criminal justice decisions, the contemporary executive operates in an environment in which officials of all major parties and their constituent publics pay at least lip service to racial and gender equality as social and political norms. Is it conceivable that a governor in 2001 would publicly explain his grant of clemency to a female death row prisoner in the terms Governor West of Oregon used in 1908? "When I saw that woman in the penitentiary (the only one there), it made me sick and so I turned her loose.". 34

Before broaching the topic of how a governor might navigate capital clemency in the age of formal equality, it may be helpful to review the demographics of death row, which supply, at it were, some of the raw material for the executive decision-maker.

\section{THE DEMographics OF DEATH ROW}

Pronouncement of a death sentence in the United States is not a death knell but the commencement of a long and often multi-tiered reconsideration of the fate of the condemned. Hundreds of decisions made by reviewing courts and governors each year determine, among those under sentence of death, who will live, who will die, and who will await further process. Nationally, 9\% of those condemned, 1977-99, have been executed, although the risk is much higher in a few states and much lower in some states. ${ }^{35}$ A majority of those condemned in that period remain on death row, while approximately a third have been relieved from capital jeopardy by court action or,

34. James D. Barnett, The Grounds of Pardon, 17 J. Crim. L. \& Criminology 490,514 (1927).

35. See infra. app. tbl.1. 
rarely, by executive clemency. ${ }^{36}$ While few death row prisoners have been granted executive clemency, ${ }^{37}$ approximately two-thirds of the death sentences reviewed by courts have resulted in sentencing relief or reversal of conviction. ${ }^{38}$ The high rate of long-term or permanent survival of death sentences imposed in the contemporary death penalty era raises many questions about the system's fairness and entitlement to continued public support. The survival rate invites, among other inquiries, questions about whether men and women, whites and persons of color, enjoy similar rates of success in staying alive after imposition of a death sentence.

Women are far less likely than men to be placed under sentence of death ${ }^{39}$ and more likely than men to leave death row alive. Women exceed their condemned brothers in obtaining relief in the courts as well as in their share of the very limited number of grants of executive clemency to capital prisoners. I will review. what is known about the history of relief in the courts after condemnation for capital prisoners, and then focus my efforts on the clemency phase of the multi-tiered decision process.

\section{A. Relief on Direct Appeal, Federal Habeas, and State Post- Conviction}

The recently released Liebman Study of error rates in capital cases, 1973-1995, , $^{40}$ exposes an aspect of the contemporary death penalty system that had not previously been adequately understood. Students of capital

36. See Bureau of Justice Statistics, U.S. Dep't of Justice, Capital Punishment 1999, at 15 app. tbl.3. [hereinafter Capital Punishment 1999]. Percentages of persons executed, died, removed, and commuted.

37. See infra notes $60-61$ and accompanying text.

38. See James S. Liebman et al., A Broken System: Error Rates in Capital Cases, $\because$ 1973-1995, The Justice Project, at: http://justice.policy.net/jpreport/finrep.PDF (Mar. 13, 2001) [hereinafter A Broken System].

39. See Elizabeth Rapaport, The Death Penalty and Gender Discrimination, 25 Law \& Soc'y Rev. 367 (1991) [hereinafter Rapaport, The Death Penalty].

40. A Broken System, supra note 38 . 
punishment were well aware that, since the resumption of capital punishment was permitted by the U.S. Supreme Court in 1976, execution has been the exception, while long tenancy on death row and reduction of sentence have thus far been the fates of most capital prisoners. U.S. Department of Justice annual reports ${ }^{41}$ and NAACP quarterly reports ${ }^{42}$ toll the numbers. At of the close of 1999, almost a third of those condemned, 1977-99, had obtained sentencing relief, or, in a smaller number of cases, had their convictions reversed. ${ }^{43}$ The Liebman study has revealed that the familiar one-third relief statistic masks the astonishing success rate of capital inmates in the courts in the modern death row era. More than half of all capital cases reviewed on direct appeal by state supreme courts, on federal habeas corpus petitions, or state post-conviction review, 1973-95, resulted in reversals of sentences (or to a lesser extent, of convictions). Liebman and his co-authors found that during the twenty-three year period studied, $68 \%$ of cases reviewed at one or more of the three levels of review were found to have committed reversible error. ${ }^{44}$ Especially important is the robustness of the result, year after year and in state after state. ${ }^{45}$ "A majority of all cases reviewed in 20 of the 23 study years-including 17 of the last 19-were found seriously flawed."46 The Liebman

41. For the most recent report available, see Capital Punishment 1999, supra note 36 .

42. See NAACP Legal Defense and Education Fund, Inc., Death Row USA (Winter 2001), http://www.deathpenaltyinfo.org/DeathRowUSA1.html (Jan.1, 2001).

43. See Capital Punishment 1999, supra note 36, at 15 app. tbl.3.

44. A Broken System, supra note 38 , at i.

45. See James S. Liebman et al,, A Broken System: Error Rates in Capital Cases, 1973-1995, The Justice Project Appendices, at http://justice.policy.net/jpreport/finapp.PDF (Mar. 13, 2001) at app. E at E-5 tbl.3 [hereinafter A Broken System Appendices]. Id. at app. A at A-10 tbl.30.

46. A Broken System, supra note 38 , at 10 ; see also A Broken System Appendices, supra note 45 , at app. A at A-10 tbl.30 (revealing the state by state error rates). There are some outlying states with substantially lower percentages of reversals, notably Virginia and Missouri. Other leading execution states, including Texas, Florida, and Louisiana, have high rates of error.

The maintenance of the high error rate, over fifty percent in seventeen of the last nineteen years of the study, is particularly significant in light of the 
Study brings into sharp relief the extent to which contemporary death row is a purgatory for a special class of litigants.

\section{B. Leaving Death Row Alive: Gender, Race, and Success Rates}

As Appendix table $2^{47}$ demonstrates, women are far less likely than men to be capitally sentenced, ${ }^{48}$ less likely to be executed if capitally sentenced, and more likely to removed from under capital sentence. Other differences in male and female death sentences may also be significant, although the relatively small number of female death row prisoners requires considerable caution in extrapolating inferences. Distaff death row is substantially whiter than male death row, Blacks comprised $28.9 \%$ of women but $41.6 \%$ of men under sentence of death 1977-99. While blacks account for over a third of all executions, ${ }^{49}$ 1977-99, only one black woman has been executed in the contemporary death penalty era, joining five white women in the annals of post-Furman ${ }^{50}$ execution at this writing. ${ }^{51}$ Among the few women on death row, it appears that whites have been more vulnerable to execution than blacks and more successful than blacks in achieving sentencing relief. ${ }^{52}$

Following gender disparity, the most marked disparity

wholesale reversal of sentences produced by the overturning of pre-Gregg v. Georgia capital punishment statutes in the early years, 1973-78, of the Liebman Study's purview. See Capital Punishment 1999, supra note 36, at 13 app. tbl.1 for a tally of the reversals attributable to this source in the early years of the contemporary death penalty era.

47. See infra app. tbl.2.

48. See Rapaport, The Death Penalty, supra note 39

49. See Capital Punishment 1999, supra note 36.

50. Furman v. Georgia, 408 U.S. 238 (1972) (per curiam) (holding extant capital punishment statutes unconstitutional).

51. Wanda Jean Allen was executed in Oklahoma on January 12, 2001. See Nation in Brief, Wash. Post, Jan. 12, 2001, at A26; see also Allen v. State, 871 P.2d 79 (Okla. Crim. App. 1994).

52. The small numbers of Hispanic and other non-white women precludes generalizing about these populations. 
revealed by Appendix table 2 is the lack of success of Hispanics in leaving death row alive; Hispanics fare less well than either blacks or whites. Appendix table 2 reveals other less dramatic differences in success rates. White men are more likely to suffer execution than blacks and Hispanics, but they enjoy an advantage in their chances of leaving death row alive.

There are several possible explanations for the relative success of women in staying alive after condemnation, foremost among which is gender bias in favor of women in reviewing courts and in the breasts of other personnel of the criminal justice system. There are, however, other explanations to be canvassed. The Liebman Study results suggest an explanation that deserves especially close consideration. It may be that the advantage that condemned women have is less a matter of ultimate disparity in rates of staying alive than in the speed with which their cases are taken and disposed of by reviewing courts. Female rates of removal from under sentence of death approximate the rates that Liebman and his coauthors found among that fraction of the condemned whose cases had reached reviewing courts. The Liebman Study reported that reversible error was found in over two-thirds of the cases reviewed, ${ }^{53}$ with rates exceeding $50 \%$ in almost every year of the nineteen-year period studied. ${ }^{54}$ Women may be enjoying a kind of "fast track" advantage. The explanation of that advantage may lie, at least in part, in their being a tiny minority in the sea of the condemned; their sheer unusualness lends their cases visibility and attention denied the rank and file cases on male death row.

High as the incidence of reversible error was found to be in death cases generally, it is possible that the error rate in female death cases is higher still. Further research may reveal two types of gender-patterned reasons for higher rates of error in cases of women defendants. It may be that women death row inmates present to reviewing courts

53. See A Broken System, supra note 38 , at $\mathbf{i}$.

54. Id. at 10. 
cases with less severe aggravating factors and milder histories of violence. ${ }^{55}$ If so, females would tend to benefit more than men from any review directed to the proportionality of the death penalty to the crime. Additionally, women's capital cases, like other women's criminal cases, sometimes involve gender-patterned mitigation factors that were not-or under the law then in force could not-be adequately examined at trial. The contemporary death penalty era and the feminist effort to reform the law of homicide began at approximately the same time; ${ }^{56}$ the law of homicide continues its partial and uneasy efforts to come to terms with the reality of domestic oppression and domination by male accomplices as a factor in women's cases. Courts reviewing women's death sentences inevitably will be grappling with defense efforts to bring these issues to their attention. ${ }^{57}$

\section{CAPITAL CLEMENCY POST-FURMAN}

Executive clemency in capital cases, once commonplace, has become exceedingly rare. During the course of the twentieth century, until the 1967-76 moratorium, the incidence of executive clemency in capital cases is conservatively estimated to have been 20 or $25 \%^{58}$ Although the data are incomplete, they reveal that many states and the administrations of many governors exceeded these percentages. ${ }^{59}$ Since 1977 , there have been in excess of $6,500^{60}$ death sentences and 87 instances of executive

55. See Rapaport, The Death Penalty, supra note 39, at 376 tbl.3

56. See generally Elizabeth Schneider, Battered Women and Feminist Lawmaking (2000).

57. See Elizabeth Rapaport, Equality of the Damned: The Execution of Women on the Cusp of the 21 st Century, 26 Ohio N.U. L. Rev. 581, 584-85 (2000) [hereinafter Rapaport, Equality of the Damned].

58. See Hugo Adam Bedau, The Decline of Executive Clemency in Capital Cases, 18 N.Y.U. Rev. L. \& Soc. Change 255, 266 (1990-91); William Bowers, Executions in America, 76 n.b. (1974).

59. See Bedau, supra note 58, at 265 tbl.2; see also Note, Executive Clemency in Capital Cases, 39 N.Y.U. L. Rev. 136 app. 2 (1964).

60. The Bureau of Justice Statistics reports 6,365 death sentences at the close of 1999. See Capital Punishment 1999, supra note 36, at 11 tbl.11. Annual 
clemency in capital cases. ${ }^{61}$ Of these eighty-seven grants to death row prisoners, half, forty-three, were made for reasons of "judicial expediency." Typically, in these cases governors acted to avoid devoting resources to retrials and resentencing hearings where changes in death penalty law made by the U.S. Supreme Court invalidated the statutes under which the petitioners had been sentenced. ${ }^{63}$ Thus, only forty-four clemency grants arose from executive consideration of the merits of the cases. Fewer than two in a hundred capital prisoners have obtained commutation or pardon since the end of the moratorium.

Women capital prisoners have been more successful than men in pursuit of commutation of sentence. Of the forty-four grants of executive clemency in capital cases since 1977 decided on the merits rather than for expedient reasons, seven have been made to women. Of these fortyfour beneficiaries of executive clemency, twenty-one are black, twenty are white, two are Hispanic, and one is Native American ${ }^{64}$. Women, who have typically comprised approximately $1.4 \%$ of death row, ${ }^{65}$ are the most successful clemency seekers among the discreet populations of capital prisoners. The national tally does not on its face point to a comparable racial disparity. The actions of governors in

admissions to death row have approached or exceeded 300 in the last decade. Id. at 13 app. tbl.1.

61. Eighty-six instances of capital clemency have been by governors and one by President Clinton at the close of his term.: See Death Penalty Information Center, Facts About Clemency, at: http://www.deathpenaltyinfo.org/clemency.html. (Mar. 6, 2001) Thereinafter DPIC]. Amy Goldstein \& Susan Schmidt, Clinton's Last-Day Clemency Benefits 176; List Includes Pardons for Cisneros, McDougal, Deutch and Roger Clinton, Wash. Post, Jan. 21, 2001, at A1.

62. This term is used by Michael Radelet and Barbara A. Zsembik in their 1993 study of capital clemency. Michael L. Radelet \& Barbara A. Zsembik, Executive Clemency in Post-Furman Capital Cases, 27 U. Rich. L. Rev. 289, 292 (1993).

63. Id. at 293.

64. See DPIC, supra note 61.

65. See Victor L, Streib, Death Penalty for Female Offenders January 1, 1973, to June 30,2000 , at http://www.law.onu.edu/faculty/strieb/femdeath.htm (last visited Aug. 21, 2000) [hereinafter Streib]. Hardcopy of this document is on file with the University of New Mexico Law Library. 
women's cases, both denials and grants, have indeed been scrutinized for evidence of gender bias.

In 1984, the execution of the first woman to meet that fate since end of the moratorium, Velma Barfield, was preceded by a swirl of speculation about whether Governor Jim Hunt of North Carolina would permit the execution of woman. ${ }^{6}$ The second scheduled execution of a woman, that of Karla Faye Tucker in Texas in 1998, reprised the intense publicity and interest in the Barfield case, as the nation anticipated the decision of Governor George W. Bush. ${ }^{67}$ Because of the fourteen year separation between the two cases, Governor Bush, like Governor Hunt, was in the unenviable position of being uncertain how his constituents would react to the execution of a woman; the Barfield case was a post-moratorium novelty, and the Tucker case only the second time a governor had been so tested in fourteen years." Would the execution of a woman repel the public, make the governor appear "bloodthirsty" and hardhearted, or would mercy outrage the public's sense of fairness and make the governor appear weak? In both cases, and in four more recent cases, governors met the challenge by allowing the executions to proceed. The sharp decrease in public interest attending the most recent executions of women reflects the lesson that governors have now learned. ${ }^{69}$ Executing a woman is not dangerous to the political health of a contemporary governor. The equal justice governor need not flinch at the prospect of creating a bloodless or bloodthirsty image of himself. The public

66. See Rapaport, Equality of the Damned, supra note 57 , at 592-93.

67. Id. at 594-99. In Texas, the Board of Pardons and Paroles has the formal power to make clemency decisions. See Tex. Const. Art. IV, \& 11. But the Governor appoints the entire membership of the Board. See Tex. Gov't Code Ann. \$ 508.031 (Vernon 1998). See George Bush's account of his decisive role in the Karla Faye Tucker and Henry Lee Lucas cases in George W. Bush, A Charge to Keep 140-66 (1999).

68. Rapaport, Equality of the Damned, supra note 57, at 595-96.

69. The execution of Christina Riggs in 2000 was barely mentioned by the New York Times. See Emily Yellin, Arkansas Executes a Woman Who Killed Both Her Children, N.Y. Times, May 3, 2000, at A22. The Times carried no story at all about the most recent execution, that of Wanda Jean Allen in Oklahoma on January 11, 2001. 
accepts and expects condemned women to be treated like their male brethren. He can forthrightly proclaim his commitment to doing equal justice without fear or favor.

Seven women capital prisoners have received executive clemency since $1977 .^{70}$ All but one of these commutations was granted at the very end of the term of a governor who was not seeking re-election. The exception was Governor Jim Edgar of Illinois, who, in 1996, commuted the death sentence of Guinevere Garcia. Governor Edgar, who was enjoying exceptionally high public approval ratings, chose to all but stonewall the press with the explanation that Garcia's shooting of her ex-husband in a quarrel over money was not a "typical" death penalty crime. ${ }^{71}$ Governor Fob James of Alabama commuted the death sentence of Judith Anne Neelley on the last day of his term in 1991, refusing any explanation. ${ }^{2}$ On his last day in office, Governor Harry Hughes of Maryland commuted the sentence of Doris Ann Foster because of doubts about her role in the crime for which she was convicted..$^{3}$

Governor Richard Celeste of Ohio commuted the death sentences of eight inmates, four men and four women, at the close of his term. Six were black, including all four of the women. ${ }^{74}$ Celeste has been unusual, if not unique, among recent governors, in his willingness to use the clemency power in both capital and non-capital cases, in a variety of types of cases and circumstances. He had earlier in his term instituted a review of women convicted for killing their batterers which had culminated in twentyeight releases. ${ }^{75}$ He based his commutations in these

70. See DPIC, supra note 61 .

71. See Edgar Commutes Sentence; Guinevere Garcia, Killer of Abusive Husband, To Serve Life Without Parole, Chi. Trib., Jan. 16, 1996, at 1.

72. See Outgoing Gov. James of Alabama Commutes Woman's Death Sentence, L.A. Times, Jan. 17, 1999, at A12.

73. Foster's husband had confessed and recanted several times. See Gwen Ifill, MD. Woman's Death Term Commuted; Hughes Takes Action on His Final Day, Wash. Post, Jan. 21, 1987, at B7.

74. See DPIC, supra note 61.

75. See Linda L. Ammons, Discretionary Justice: A Legal and Policy Analysis of a Governor's Use of the Clemency Power in the Cases of Incarcerated Battered Women, 3 J.L. \& Pol'y 2 (1994). 
capital cases in part on concerns about racial injustice in Ohio's death penalty system. ${ }^{76}$ Governor Celeste cited a variety of uncontroversial reasons for commuting the sentences of the four women: doubts : about guilt; low intelligence or mental illness; lack of equity of a death sentence when an equally or more guilty co-defendant escaped the death penalty.

All four of these governors were at least partially politically insulated from the slings and arrows of criticism by either, in Governor Edgar's case, extraordinary popularity, or, in the case of the three remaining governors, freedom from the need to calculate the impact of their actions on their chances for re-election.

\section{Two Thought Experiments}

Let us rehearse the clemency decisions of two hypothetical contemporary governors, each of whom would like to commute the death sentence of a woman capital prisoner. Governor Knight would like to commute Magdalene Smith's death sentence because he is repelled by the exaction of so heavy a price from a woman. Magdalene calls forth his protective instincts; he believes women lack male capacity for judgement and self-control as well as male fortitude to bear harsh punishment. Although he is persuaded that. Magdalene hired a man to shoot her husband to be rid of him and for the insurance proceeds, he would prefer to commute her sentence to life imprisonment rather than to permit her execution. Governor Newman would like to commute Patience Robinson's death sentence because he finds gender-patterned mitigation in her case. Patience was horribly abused throughout her marriage at the age of sixteen to a sadist; her husband coerced her to participate in his brutal murders of two young women. Governor Newman believes these issues were given inadequate attention in her trial and sentencing. 10A.)

76. See Kobil, supra note 5, at 629 (citing Columbus Dispatch, Jan. 2, 1991, at 
Both governors have plenary clemency authority under the constitutions of their respective states. The object of the exercise is to explore the political, legal, rhetorical, and philosophical context in which the contemporary governor operates should he be moved to grant this rare boon to that rare bloom, the female capital prisoner. ${ }^{77}$

Regardless of whether an equal protection claim could be raised in a legal forum protesting the denial of clemency, the contemporary governor faces an equal protection dilemma in the political forum when he or she is bold enough to grant clemency. Frank use of state power to maintain the subordination of women or minorities of color is not good politics today. Political necessity would require the governor who wanted to indulge his prejudices or pander to those of his constituents to insist that both he and his constituents disdained discrimination in all its forms. Public relations, or "spin," however, are only a part of the contemporary governor's problem.

In his philosophical analysis of the concept of mercy, Jeffrie Murphy has popularized what he calls two "paradoxes" of mercy discussed in the writings of St. Anselm. ${ }^{78}$ Both of these paradoxes explore the apparent incompatibility of justice and mercy. The first paradox asks how a just God (or secular authority) can spare the wicked when justice demands the exaction of the full measure of punishment? ${ }^{79}$ Murphy calls the second paradox as "a kind of 'equal protection' paradox": 80 Merciful remission of punishment, whether by the divine ruler or an earthly governor, can be met by protests from sinners or criminals similarly situated to the recipient of mercy. Perplexed humanity asks God:

77. In half the states that currently have a female on death row, she will be "the only one there." Id. at 514. At the close of 1999, nine out of eighteen states with women on death row had a solitary woman prisoner. See Capital Punishment 1999, supra note 36 , at 8.

78. See Jeffrie C. Murphy, Forgiveness, Mercy and the Retributive Emotions, Crim. Justice Ethics 3 (Summer/Fall 1988).

79. Id. at 11.

80. Id. at 13. 
But if it can in some way be grasped why You can will to save the wicked, it certainly cannot be understood by any reason why from those who are alike in wickedness You save some rather than others through Your supreme goodness, and damn some rather than others through Your supreme justice. ${ }^{81}$

From these paradoxes we can fashion two dilemmas facing executives rendering clemency decisions. I speak of dilemmas rather than paradoxes because a governor faces more than an intellectual puzzle. The contemporary executive contemplating granting clemency confronts potential political harm whenever he or she makes a clemency decision. The commutation of Judith Ann Neelley's death sentence by Governor Fob James of Alabama at the end of his term in 1999 precipitated a call for constitutional amendment to strip the governor of clemency power. ${ }^{82}$ Governor Celeste's commutations of eight death sentences, including all four women on death row, induced the Ohio attorney general to challenge several of the commutations in court. ${ }^{83}$

And yet the governor must act, must choose either to grant or deny. In a case ripe for clemency in his own eyes or those of his constituents, shall a governor grant clemency and appear deficient in justice or withhold it and appear deficient in compassion (perhaps principally, but no less painfully, in his own eyes)? Will a governor who grants clemency be compelled to grant further clemency in any like case or endure accusations of arbitrariness or bias?

These dilemmas are intimately associated with a particular and ascendant view of criminal justice, retributivism. $^{84}$ Retributivists measure the amount and

81. St. Anselm, Proslogion ch. XI, at 131-33 (M.J. Charlesworth trans., 1965).

82. An Alabama state senator proposed a constitutional amendment to strip the governor's power to commute death sentences. See Mike Cason, Bill Would Remove Power to Commute, The Montgomery Advertiser, Jan 20, 1999, at 1A.

83. See Ohio Attorney General Contests Clemencies, Chi. Trib., Jan. 30, 1991, at 11 .

84. See Moore, supra note 8 (defending retributivism). But see Rapaport, Retribution and Redemption, supra note 8 , at 1501 (offering a critique of 
severity of just punishment by the seriousness of the offense and the culpability of the offender. Retributivists are suspicious of leniency unless it is employed to correct excessive or undeserved punishment. If the clemency power is employed to do remedial justice, no genuine leniency is granted, since the remitted punishment was undeserved. To remit unjust punishment is a duty of justice not a discretionary act of mercy. Traditional uses of the clemency power encompass effecting remedial justice but they also encompass the grant of mercy to those retributively undeserving. Such traditional grounds for clemency as post-sentencing reformation, good works, or the needs of family outside the prison walls are rejected. ${ }^{85}$ Similarly rejected are what might be termed acts of pure mercy, such as Christmas releases. Putatively merciful uses of the clemency power are either mischaracterized acts of remedial justice or they are morally unjustified derogations from strict retributive justice. Retributivists are thus at best grudging in their toleration for an important traditional use of executive clemency sanctioned by the Founders, the healing of political and social divisions through leniency to rebels and dissidents. ${ }^{86}$

With respect to the first dilemma, premised on the retributivist view that mercy cheats justice, a governor who contemplates a grant of clemency has a choice between grasping one horn of the dilemma or attempting to go between the horns by embracing non-retributivists grounds for clemency. Governor Knight, for example, might be able to satisfy his critics that granting clemency to Magdelene Smith is remedial justice rather than a sentimental deviation from justice. Governor Knight might be able to justify granting clemency to Magdelene Smith on these grounds, if hers was one of three comparable hired assassin cases in the state and the other two received life sentences. Commutation of her sentence could be justified as bringing

retributivism).

85. See Barnett, supra note 34 , at 519-24; W.H. Humbert, The Pardoning Power of the President 124-33 (1941).

86. See Moore, supra note 8 , at 88-98. 
her punishment in line with those meted out in other cases. Governor Newman might similarly be able to justify clemency for Patience Robinson on the grounds that her mental retardation and the extremity of her psychological thralldom to her husband reduce her level of culpability, establishing that she did not deserve the death penalty. Alternatively, Governor Knight might go between the horns of the dilemma, insisting that justice has nonretributive dimensions. He might proclaim that Magdelene has rehabilitated herself, becoming a sincere Christian and that she therefore deserves clemency.

The equal protection dilemma typically poses a graver threat to the governor seeking to justify a clemency grant. ${ }^{87}$ At the outset of discussing the politics of equal protection in clemency cases, it is worth noting that criticism on these grounds is all but certain when a contemporary governor awards clemency, in good part because grants of clemency have become so rare. The more loathe governors have become to exercise their power of clemency, the more vulnerable they are to the charge that the successful inmate is no more deserving than others who have not received the boon. Thus, the very great and unusual good luck of the successful petitioner makes him or her appear not only a favorite of fortune but at best arbitrarily selected and at worst, the beneficiary of executive bias.

In making clemency decisions, executives face both weak and acute versions of the equal protection dilemma. The strong version comes into play when a grant of clemency is perceived to be tainted by discrimination based on race, gender, or religion. The weak version of the dilemma confronts a governor virtually any time he or she makes a clemency decision. The weak version comes into play when a grant appears merely arbitrary, although not tainted with proscribed bias. Clemency decisions will be examined to allay or confirm the suspicion that they do not meet modern expectations that governmental actions will

87. It is assumed here that grants are more politically problematic than denials. See Rapaport, Equality of the Damned, supra note 57, at 592-97. 
consistently apply appropriate standards. Thus, criticism and unease surrounded Governor Mel Carnahan of Missouri's 1999 commutation of the death sentence of Darrell Mease in deference to a plea for mercy from visiting Pope John Paul II. ${ }^{88}$ A governor can expect criticism whenever he or she does not enact the even-handed stance.

An executive has several possible means of explaining, justifying, and defending his action when he is accused of being merely arbitrary but not biased. He can say that he fully intends to act consistently in any future case. So, for example, a governor who opposes capital punishment on religious grounds-as was the case with Toney Anaya of New Mexico, who commuted the sentences of all five men on death row before he left office in 1986-could say that he will never permit an execution on his watch. ${ }^{89}$ Or, a governor can adopt a policy - as did Governor Herbert Lehman of New York, among other governors-of always commuting in a death case if there was a dissent in the case on appeal to the state's highest court. ${ }^{90}$ A governor can institute a comprehensive review of cases of a certain type with a view to granting relief to a class of prisoners. Several governors have instituted review of cases of women prisoners, capital and non-capital, who killed their batterers and were convicted before the law of their states allowed more recently developed battering defenses. The criteria developed and the releases of prisoners who met them satisfied the demand for treating like cases alike. ${ }^{91}$

But a governor may also reject demands for criteria

88. See Gustav Niebuhr, Governor Grants Pope's Plea For Life of a Missouri Inmate, N.Y. Times, Jan. 29, 1999, at A1; Hanna Rosin, Heeding Pope's Personal Appeal, Governor: Blocks Death Sentence, Wash. Post, Jan. 29, 1999, at A; Pam Belluck, Clemency for Killer Suprises Many Who Followed Case, N.Y. Times, Jan. 31,1999 , at 1.

89. See Toney Anaya, Clemency and Pardon Symposium: Statement by Toney Anaya on Capital Punishment, 27 U. Rich. L. Rev. 177 (1993).

90. See Henry. Weinstein, Issue of Clemency is Davis Most Difficult as Governor; Death Row; He must Choose Whether to Spare an Inmate Set to Die on Tuesday. Such Requests are Now Rarely Granted, L.A. Times, Feb. 6, 1999, at A1.

91. See Ammons, supra note 75 (discussing the investigation and releases in Ohio during the administration of Governor Celeste). 
and consistency with some political confidence. A governor may defend a grant, let us say, to a mentally retarded inmate whose sentence he commutes in a death case, by insisting on his constitutional duty to examine the case and to make a conscientious decision as to whether public mercy should be bestowed. This kind of justification insists on the prerogative, on the value of tempering justice with mercy, and on the duty of personal judgment in the public's name "in the light of all circumstances and the passage of time." ${ }^{.92}$

Any of these rhetorical approaches may serve the governor well unless a clemency grant or denial raises equal protection issues of the acute kind; if a decision is read as resting on race, gender, or religious bias, or favoritism, the executive will be faced with more than protests about lack of consistency and a failure to articulate and respect standards. He or she will have to withstand charges in the political arena of racial or gender bias.

The Supreme Court has not yet taken the case that would decide whether equal protection applies to clemency decisions. Should future federal or state constitutional law permit equal protection review of clemency decisions, extant equal protection law suggests that prisoners challenging the use of discretionary power would face virtually insurmountable proof requirements. In McCleskey v. Kemp, ${ }^{93}$ the Supreme Court held that statistical proof of racial discrimination by Georgia juries in death penalty cases would not avail McCleskey; to prevail he would have to prove racial bias influenced the jury in his trial. Likewise equal protection claims challenging the use of a prosecutor's preemptory challenges to purge juries of members of a race or sex require proof of discriminatory intent. ${ }^{94}$ Even if challenges to a governor's clemency decisions were permitted to rely on statistical

92. Terry Sanford, On Executive Clemency, in Messages, Addresses and Public Papers of Governor Terry Sanford, 1961-1965, at 552 (1966).

93. 482 U.S. 920 (1987).

94. See Batson v. Kentucky, 476 U.S. 79 (1985); J.E.B. v. Alabama, 511 U.S. 127 (1994). 
patterns to establish intent, prisoners would have the daunting burden of finding a statistically cogent pattern in a tiny universe of cases. Since the contemporary governor is unlikely to announce that race or gender was the basis of a grant or denial, it is damage in the political rather than the legal arena from which he will anticipate having to defend his decisions. If race, gender, or religion is perceived to have played a role in a grant, a governor may be embarked on perilous seas.

Let us assume that both Governors Knight and Newman are planning to run for re-election. Neither regards himself as politically invulnerable. Presumably neither governor will be as willing as a retiring governor to endure stoically the potential criticism that commutation of sentence was inspired by gender bias. Knight and Newman risk being weakened politically by the perception that gender bias has corrupted justice, whether because of the genuine sympathy of the governor for the gentler sex or his own perception of the utility of pandering to such sentiments in the electorate. Despite the political risks, the governors would like to persevere, to grant clemency.

Governors Knight and Newman would each like to grant clemency to a woman, at least in part, because of her sex. The governors understand that political risk lies in granting, not denying clemency, but neither is so riskaverse as abandon consideration of a grant without working through the analysis. Governor Knight wants to protect Magdalene from the full legal eonsequences of her crime. He is willing to take some political risks to avoid having a hand in the execution of woman. Although a proponent of capital punishment, he believes that the execution of a woman would dishonor him. Governor Newman is a feminist. He is contemplating accepting the risk of granting clemency in Patience Robinson's case in order to call attention to the need for criminal justice reform to incorporate recent advances in understanding, as he sees it, of the circumscribed agency of battered women. 


\section{A. Governor Knight's Dilemma}

Governor Knight is motivated by a patriarchal constellation of personal values. He knows he has little to fear from his constituents if he allows the execution of Smith. He has studied the execution of Karla Faye Tucker in neighboring Texas and other recent cases in which governors have allowed the execution of women without suffering political decline. His problem is how to package the clemency to avoid criticism for failure to administer the death penalty even-handedly and failure to give the death penalty the unstinting support he has pledged. He would like to think that many of his constituents harbor.instincts that would lead them to welcome the Smith commutation. Although recently governors have not been bold or subtle enough to appeal to such sentiments, perhaps he can. Knight rules out going public with his reason for commuting. He does not want to be the fodder for an equal protection case challenging the constitutionality of gender bias in the use of the clemency power. Nor does he wish to be pilloried for his lack of even-handedness by the press. $\mathrm{He}$ also rules out the costly rhetorical strategy of stonewalling the press and the public. A governor who plans to seek re-election or other office cannot afford to follow the recent example of Fob James of Alabama. ${ }^{95} \mathrm{He}$ would suffer unacceptable press criticism and be discredited if he attempted to use his prerogative without an acceptable public explanation.

Governor Knight is dismayed to find that there are no factors in mitigation in the Smith case that were given short shrift at trial or sentencing or that have come to light in the eight years since her condemnation. Nor has his legal counsel found any tenable basis to claim that she has been punished more severely than others who have committed like offenses in the state. The staffer tasked with combing through the history of her marriage to the victim-husband regretfully reports, "Sorry, chief, he adored

95. See The Montgomery Advertiser, supra note 82 . 
her. She did it strictly for the money, so that she and the boyfriend could live in the same style." The social and psychiatric history is just as daunting. Magdalene Smith was at the time of her trial without affliction save for certain indicia of a sociopathic personality. The product of an unremarkable lower-middle class home, and of two hardworking and responsible parents, Magdalene is of superior intelligence and college educated. The psychiatric evaluation ordered for her clemency proceedings revealed that she is as sane and competent as any man or woman on death row.

Magdalene Smith is a convert to Christianity. After three years residence on death row, she became a devout evangelical Christian. Her sincerity was attested to by prison chaplains and corrections personnel. Although at trial she has protested her innocence, she owned her guilt immediately after her conversion. She has admitted her responsibility to her husband's family and offered what apology she could. Governor Knight considers basing his public explanation of clemency on her religious rehabilitation. He hopes to find support among the evangelical Christian community in his state, some of whose leadership have called for mercy for Magdalene Smith. His staff has little difficulty persuading him of the obstacles he faces. His chief of staff informs him that there are at least twenty inmates on the state's death row who are devoutly religious. The Governor has denied clemency to two Christian and one Muslin male capital petitioners since assuming office. A junior staffer suggests clemency be given to all sincere religious practitioners. The idea is not seriously discussed. "How," asks the Governor, " can we cut her out of that pack without saying we are giving her special consideration because she is a woman?"

Governor Knight finds himself left with two alternatives, commuting without explanation or allowing the execution to go forward. Gender bias and plenary power will in all likelihood not be enough to save Magdalene Smith's life. 


\section{B. Governor Newman's Dilemma}

Governor Newman, unlike Governor Knight, would like to call attention to Patience Robinson's sex in explanation of his grant of clemency. He wants to advocate for law reform on behalf of battered woman as well as spare her life.

Governor Newman, I submit, has the easier, but not an easy, political and rhetorical task. Governor Newman can attempt a two-part justification for his decision to commute. He can rest his decision in part on the retributivist ground, widely shared if not uncontroversial, that mental illness and retardation ought to mitigate guilt. Nine of the forty-four post-Furman grants of clemency in capital cases on humanitarian grounds were similarly supported. ${ }^{96}$ He can further make the case that gender is relevant to analysis of Patience Robinson's culpability. Patience's malevolent husband, he believes, was a classic, extreme abuser and their relationship a hideous example of domestic oppression. He finds gender-patterned mitigation in the case that was not given sufficient weight or attention at her trial and sentencing under the law at the time of her conviction. Newman can justify commutation in part as rectification of an unjust outcome. Several capital clemencies by contemporary governors suggest that they were moved by domestic oppression themes. Clemency for Robinson is therefore not arbitrary. It is supported by reasons that ought to be resonant for substantial portions of his public.?

But the governor is now vulnerable to the charge that his decision discriminates on the basis of sex. The death

96. See DPIC, supra note 61 . At least thirteen states have thus far enacted legislation prohibiting the execution of the retarded. See id.

97. At least three battered women capital prisoners have received clemency in the post-Furman era, Debra Brown (under sentence of death in both Indiana and Ohio), Guinevere Garcia, and Judith Ann Neelley. Brown and Neelley, like the hypothetical Robinson, were women who were subject to extreme duress by husband-accomplices. See Brown v. State, 698 N.E.2d 1132 (Ind: 1998); State v. Garcia, 651 N.E.2d 100 (Ill. 1995); Neelley v. State, 494 So.2d 669 (Ala. Crim. App. 1985). 
row of Newman's state contains men who have mental retardation or mental illness, and who have suffered familial abuse. Patience's husband, who has a documented history of having suffered severe abuse in childhood, is contemplating an equal protection challenge to the denial of clemency in his case if his wife is successful in obtaining clemency for the same crimes.

Perhaps Newman can deflect criticism with a little nimble rhetoric, portraying himself as a practical statesman, one who must meet the day's challenges as they come. Unlike Governor Knight, his reasons are respectable; he is not casting about for a means of masking an officially discredited if still potent ideology. It should be noted, however, that if gender were to appear as a statutory mitigating factor in capital crime reform legislation, it would be struck down on equal protection grounds. The Supreme Court has ruled that men are as entitled to protection from discriminatory gender classifications as are women and that gender cannot be used as a proxy for characteristics that can be found in both sexes simply because they are more prevalent in men or women. ${ }^{98}$ If Governor Newman's state wishes to enact domestic violence victim mitigation in response to the Patience Robinson case, and other types of death penalty cases in which domestic oppression is at work, gender neutrality should be respected. ${ }^{99}$

The Governor is facing two related hurdles. He would

98. See United States v. Virginia, 518 U.S. 515, 533 (1996); Mississippi Univ. for Women v. Hogan, 458 U.S. 718, 726 (1982).

99. The following two mitigating circumstances employing gender neutral language were proposed as part of a bill to reinstitute the death penalty in the Massachusetts legislature in 1991:

(3) the murder was committed while the defendant was under extreme duress or under the domination or control of another which was insufficient to establish a defense to the murder but which substantially affected his judgment; ...

(6) the defendant was battered or otherwise physically or sexually abused by the victim in connection with or prior to the murder for which the defendant was convicted and such abuse was a contributing factor in the murder.

H.B. 6291,177 th Gen. Ct., Reg. Sess. (Mass. 1991): 
like to be able to use the clemency power in an exemplary fashion. He would like to call attention to the need for criminal law reform to avert injustice to battered womenand all people with mental deficiencies and afflictionswithout committing himself to granting clemency in all like cases. Newman is no great friend of the death penalty. He would cheerfully sign legislation to abolish it. His circumspection arises from practical politics and a view of his institutional role as governor of his state. If he were to grant clemency to the perhaps dozens of men on death row in his state with credible claims to mercy on the grounds of their mental disability, he would undermine his ability to press his overall political agenda as well as his political future. He is unwilling to spend the political capital of his career and administration to reduce temporarily the death row population of his state. Newman also believes that lasting reform must come from the legislature. Although he has the power to halt capital punishment in his state for as long as he is in office, he does not believe it would be a proper use of the clemency power to supercede legislative control of the criminal code.

Governor Newman seeks advice from his legal counsel and chief of staff: "I don't feel as strongly as Toney Anaya did about capital punishment, nor do I have the luxury of being at the close of my career in electoral politics. I do feel strongly about women like Patience Robinson being victimized, ignored by society until they break the law, and then made to pay with their lives. Fortunately for me, there is no other woman on death row with a case that raises similar issues. I would like to do something to call attention to this injustice and grant mercy in her case. I can't repair the systematic failures of the whole criminal justice system in this state. I want to do a little retail justice here. Is there some way to employ my "plenary power" without exposing myself to legal embarrassment and real political damage?"

The Governor's legal counsel tells him that no court in the state, nor any federal court, has ever held that a clemency decision must conform to the equal protection 
standards imposed on legislation. It is his view that under current law, an equal protection challenge by a male prisoner denied clemency would fail to state a justiciable claim. ${ }^{100}$ In the unlikely event that the prisoner got his day in court, his case would founder because Newman had no purpose to discriminate against such male or in favor of Patience Robinson because of sex. "Governor," he muses, "You have shown your willingness to grant clemency to a male petitioner. Your one grant of capital clemency to date was to a retarded male prisoner. If your second grant is to a female prisoner, and your public explanation is careful to emphasize that women bear the brunt of domestic violence, although they are not the exclusive victims of it, you have little to fear."

Governor Newman believes he needs more help to prepare his public explanation. He describes the political climate as one in which the public is increasingly sensitive to, and intolerant of, government actions that appear to favor or disfavor one race or gender. "There are equal justice landmines out there. Who would have predicted that a governor could get in trouble for condoning racial profiling of black motorists?"101

The chief of staff, hesitates, then comments, "Governor, if we are legally in the clear, I think the commutation can be satisfactorily explained to the people of this state. I will write a memorandum outlining the points of constitutional theory and moral philosophy upon which we can rely. You and your speech writers can take it from there." The memorandum makes the following three theoretical "talking" points.

(1) Rejection of Strict Retributivism as the Sole Virtue of the Criminal Justice System.

Retributivists would restrict or reduce the legitimate use of executive clemency, at least in ordinary criminal

100. See Wigglesworth v. Mauldin, 990 P.2d 26 (Ariz. 1999).

101. See David Kocieniewski, Whitman and State Police: One Answer, Many Questions, N.Y. Times, Mar. 7, 1999, 14NJ, at 2. 
cases, ${ }^{102}$ to the rectification of retributively unjustified punishment. While achieving retributive justice is an important part of the overall scheme of the criminal justice system, the history of the use of clemency reveals that American executives have not so restricted their use of the clemency power.

The idea that at least occasional displays of public mercy are a good thing, even when not required to rectify excessive punishment, remains intelligible in our political culture. Rehabilitation is probably the most common nonretributive reason for granting clemency. But the exercise of the virtue of compassion for its own sake has also been an accepted ground for clemency. ${ }^{103}$ Although roundly criticized as capricious and unfair, ${ }^{104}$ the commutation of Darrell Mease's death sentence by Governor Carnahan of Missouri in response to a plea for mercy from John Paul II was probably well received by some Catholic and NonCatholic Missourians. It has been the custom of many governors to release prisoners at the Christmas season, both prisoners who were approaching their release date and some who were receiving significant reductions in their sentences. ${ }^{105}$ These releases are accepted, apparently, because it is believed that it is beneficial for the state to yield from time to time and for the executive to represent the merciful face of the people. The relentless pursuit of strict retributive justice does not appear to be desirable in our gods or in our government. ${ }^{106}$

102. I distinguish the use of clemency in "ordinary criminal cases" from its "political" uses to calm or heal social and political divisions.

103. See Barnett, supra note 34, at 491-95.

104. On Feb. 5, 1999, the Joplin Globe published the following opinion: One man's life has been spared for no other reason than papal intercession. There was no new mitigating evidence or even the hint of injustice under the law. But Mease will avoid the death penalty and the man next in line for execution, James Edward Rodden, will find himself strapped to a gurney and administered a fatal injection at one minute after midnight on Feb. 24 with only the hope of new evidence for a reprieve.

Editorial, Joplin Globe, Feb. 5, 1999, at 7A.

105. See Barnett, supra note 34 , at 492.

106. St Anselm's paradoxes suggest to retributivists that the contradiction between mercy and retributive justice be resolved in favor of retributive justice. 
(2) The Moral Duty of Mercy, Public and Private.

Moral philosophers sometimes distinguish between duties of perfect and imperfect obligation. The distinction is between duties where a correlative right exists in someone who can morally and perhaps also legally demand it be discharged and duties where no correlative right holder exists. The duty of charity is an example of a duty of imperfect obligation. No alms seeker has a right to the charity of any particular potential donor, although a person who was rarely charitable would over time fail to discharge his or her obligation of charity. The duty to repay a debt exemplifies duties of perfect obligation; a correlative right holder to whom payment is due may demand payment. Private mercy and the public mercy of clemency can be understood as duties of imperfect obligation. A governor who never granted clemency would fail, as would the public he or she represented, to fulfill the duty to be merciful. Retributivists treat clemency as a perfect obligation of justice rather than a duty of imperfect obligation which functions as part of a complex set of institutional criminal justice arrangements designed to serve retributive justice and other ends.

(3) The Institutional Role of Executive Clemency.

The Founders vested the executive with plenary clemency power in Article II of the Federal Constitution in order to accomplish two ends. They sought to give the executive the means of forestalling and healing conflict "[i]n seasons of insurrection or rebellion." "107 They sought to remedy a defect of criminal justice understood by

For some, the appeal of mercy is as powerful as that of retributive justice. Nor does retributively undeserved mercy lack a place in western religious tradition. When God appeared to Moses at Sinai-at the birth of the relationship between God and the Hebrews, and of the Judeo-Christian tradition-God described himself to Moses as merciful and forgiving. Exodus 34:6-7 (King James).

107. The Federalist No. 74 (Alexander Hamilton). 
statesmen at least since the time of Aristotle. ${ }^{108}$ The Aristotelian case was made by Alexander Hamilton in Federalist Number $74,{ }^{109}$ and made best by James Iredell, "[i]t is impossible for any general law to foresee and provide for all possible cases that may arise; and therefore an inflexible adherence to it, in every instance, might frequently be the cause of very great injustice." 110

Two functions of the clemency authority in criminal justice are to curb the rigor of the law when good policy requires it and to heed the equities in individual cases which may argue for making an exception to the general rule that apparently applies to them. A third function of the clemency authority carried over from the English system is the correction of failures of justice resulting from judicial, police, or prosecutorial bias, or want of evidence later available. ${ }^{111}$

The correction of error and equitable functions are not exclusively given to the executive. Courts may at times act in the interests of justice rather than in strict adherence to a rule of law. Prosecutors may decline to prosecute a case of "unfortunate guilt." Ins Institutional overlap or redundancy is part of the constitutional scheme and is an indication of the critical importance of the rectification and adjustment functions in sustaining a system of criminal justice.

It should be presumed that the executive develops procedures, standards, and precedents in the effort to discharge his or her clemency duties responsibly. The

108. Aristotle, Nicomachean Ethics, in Basic Works of Aristotle 1019-20 (Richard McKeon ed., 1941).

109. "The criminal code of every country partakes so much necessary severity, that without an easy access to exceptions in favor of unfortunate guilt, justice would wear a countenance too sanguinary and cruel." Hamilton, supra note 107.

110. 4 Jonathan Elliot, The Debates in the Several State Conventions, on the Adoption of the Federal Constitution as Recommended by the General Convention at Philadelphia in 1787111 (2d ed. 1861). (James Tredell, North Carolina Ratifying Convention, 29 July 1788).

111. Cf. Ex Parte Wells, 59 U.S. 307, 311 (1885) (holding that the constitutional meaning of clemency or pardon is to be interpreted by following English law and precedents).

112. Hamilton, supra note 107. 
critical difference between executive clemency and judicial decision making is that the executive remains free to follow or decline to follow precedent in a thoroughly analogous case. Presumptively, a like case will be treated alike in clemency proceedings. But the presumption can be overcome. It would be unworthy to defend executive prerogative to decline to follow precedent by exaggerating the different textures and qualities of putatively similar cases. There are unusual cases, even unique cases, but there are also new cases which share relevantly similar patterns of equitable considerations with decided cases.

The executive has institutional reasons to decline, sometimes, to treat like cases alike. The executive clemency power is so broadly defined in the federal constitution and in the majority of states as to make it legally conceivable that a governor could thwart the enforcement of any criminal law he or she found objectionable. A liberal governor might free prisoners convicted of narcotics possession offenses. A conservative governor might free all those convicted of violating certain gun control measures or of illegal interference with the operation of abortion clinics. In the arena of capital punishment, there have been governors who would not allow execution. Such decisions can be courageous and admirable. ${ }^{113}$ The difficulty is that the systematic thwarting of duly enacted legislation, whether popular or unpopular, will appear as a usurpation of legislative authority, as the abuse rather than proper deployment of a constitutional power. A governor who attempts to undo the criminal code risks undermining his credibility and effectiveness in office. A governor who opposed capital punishment, or an opponent of capital punishment for a certain class of offenders, for example, might decide to grant clemency in some egregious cases of injustice while declining to act in all similar cases in order to husband his

113. There are some instances of systematic use of the clemency power to countermand objectionable laws. "Governor Donaghey of Arkansas pardoned hundreds of convicts because of his opposition to the convict labor system of that state. ..." Barnett, supra note 34, at 517. 
political capital. ${ }^{114}$

Governor Newman digested the memo, thought his own thoughts, and decided to commute the death sentence of Patience Robinson to life imprisonment. The following paragraph was included in the press release, which also described her limited mental capacities and her marital history:

As governor I am charged with the exercise of the power of mercy in the name of the people. The people of our state are a just people but they are also a merciful people. My conscience will not allow me to fail in my duty to them. Patience Robinson, equipped with the mind of a ten-yearold, was subjected to years of unspeakable abuse by her husband, who directed her criminal action. Justice as well as mercy are served by sparing her life. Her case calls out to the people and the legislature of this state to protect victims and potential victims of domestic terror and to reserve capital punishment for the most culpable killers. I know that some of my fellow citizens, good and just people, will disagree with my decision. I will not turn away from my responsibility to exercise the power of clemency in a case that, in my judgment, is deserving of mercy and teaches a powerful lesson about the need for criminal justice reform in our state.

\section{CONCLUSION}

A grant of clemency to the hypothetical Patience Robinson is justifiable both retributively, because she has been excessively punished relative to her culpability, and because of its exemplary role in calling attention to the case for reforming the law to accommodate the lives of

114. Governor Pat Brown of California, an opponent of capital punishment, recounts the painful experience of allowing a mentally defective murderer to go to his death to avoid losing the swing vote on a piece of important social legislation. The legislator would have opposed the legislation had Brown commuted the sentence. See Kobil, supra note 5, at 608 (discussing Edmund G. Brown \& Dick Adler, Public Justice, Private Mercy (1989)). 
battered women and others similarly situated.115. An explicitly exemplary use of the clemency power goes a bit beyond the rhetorical range of recent governors. It supplies something of the universality, or link to like cases, that contemporary equal justice norms press executives to respect. But it does not overload the institution of clemency with comprehensive responsibility for the reform of criminal sentencing. Unlike a grant of clemency to the hypothetical Magdalene Smith, no violation of a governor's (currently unenforceable) constitutional equal protection duty taints the grant. While exemplary uses of the clemency power are fraught politically, they are not necessarily undertaken for proscribed reasons. Such grants may survive equal protection analysis directed to the examination of the motives of the executive.

Equal protection analysis of executive clemency decisions should not be confounded with a moral imperative to banish from criminal justice all nonretributive grounds of justice. Nor should the failure of a governor always to treat like cases alike in clemency decisions be judged a failure to perform the constitutional or moral duty to be merciful. A governor may sometimes sacrifice an opportunity to be merciful for a sufficient reason. His duties in clemency cannot be insulated from his political responsibilities. Such denials are tragic for the executive and socially, an expression of the practical limitations on a power virtually without formal limits.

The institution of executive clemency is the wrong institution to look to for systematic criminal justice reform. Executive clemency cannot adequately address the systematic distortions of criminal justice created in the last quarter of a century not only by the contemporary capital punishment system, but by other draconian sentencing policies, the demise of judicial discretion, and the partial

115. Similarly, Governor Celeste cited racism in the application of the death penalty as at least a partial basis for granting clemency to some black death row prisoners. Some governors have followed a parallel course in cases of mentally retarded death row prisoners, using the clemency power to respond to a morally compelling but legally inchoate claim. 
dismantling of parole. These tasks require the creation of a political will to support reform legislation. If we imagine criminal justice to be a vessel at sea, clemency can be analogized to a pail with which the executive can bail out the sea water of unjust punishment. The best criminal justice boat imaginable will need bailing. The boat we are in has some sizeable holes in the hull. The holes are bad criminal laws and policies. The boat will sink unless the hull is repaired. 
Appendix table 1. Number of prisoners sentenced to death and executed by state 1973-1999.

\begin{tabular}{|c|c|c|c|}
\hline State & $\begin{array}{c}\text { Total Sentenced to } \\
\text { Death }\end{array}$ & Total Executed & Percentage \\
\hline Alabama & 314 & 19 & $6.05 \%$ \\
\hline Arizona & 223 & 19 & $8.52 \%$ \\
\hline Arkansas & 94 & 21 & $22.34 \%$ \\
\hline California & 722 & 7 & $.97 \%$ \\
\hline Colorado & 17 & 1 & $5.88 \%$ \\
\hline Connecticut & 7 & 0 & $0 \%$ \\
\hline Delaware & 40 & 10 & $25.0 \%$ \\
\hline Florida & 821 & 44 & $5.36 \%$ \\
\hline Georgia & 289 & 23 & $7.96 \%$ \\
\hline Idaho & 37 & 1 & $2.70 \%$ \\
\hline Illimois & 273 & 12 & $4.40 \%$ \\
\hline Indiana & 92 & 7 & $7.61 \%$ \\
\hline Kansas & 3 & 0 & $0 \%$ \\
\hline Kentucky & 71 & 2 & $2.82 \%$ \\
\hline Louisiana & 196 & 25 & $12.76 \%$ \\
\hline Maryland & 48 & 3 & $6.25 \%$ \\
\hline Massachusetts & 4 & 0 & $0 \%$ \\
\hline Mississippi & 163 & 4 & $2.45 \%$ \\
\hline Missouri & 158 & 41 & $25.95 \%$ \\
\hline Montana & 15 & 2 & $13.33 \%$ \\
\hline Nebraska & 24 & 3 & $12.50 \%$ \\
\hline Nevada & 127 & 8 & $6.30 \%$ \\
\hline New Jersey & 48 & 0 & $0 \%$ \\
\hline New Mexico & 26 & 0 & $0 \%$ \\
\hline New York & 8 & 0 & $0 \%$ \\
\hline North Carolina & 468 & 15 & $3.21 \%$ \\
\hline Ohio & 351 & 1 & $.28 \%$ \\
\hline Oklahoma & 294 & 19 & $6.46 \%$ \\
\hline Oregon & 46 & 2 & $4.35 \%$ \\
\hline Pennsylvania & 323 & 3 & $.93 \%$ \\
\hline Rhode Island & 2 & 0 & $0 \%$ \\
\hline South Carolina & 163 & 24 & $14.72 \%$ \\
\hline South Dakota & 3 & 0 & $0 \%$ \\
\hline Tennessee & 192 & 0 & $0 \%$ \\
\hline Texas & 829 & 199 & $24.0 \%$ \\
\hline Utah & 26 & 6 & $23.08 \%$ \\
\hline Virginia & 123 & 73 & $59.35 \%$ \\
\hline Washington & 34 & 3 & $8.82 \%$ \\
\hline Wyoming & 11 & 1 & $9.09 \%$ \\
\hline Federal & 22 & 0 & $0 \%$ \\
\hline
\end{tabular}

*Based upon Bureau of Justice Statistics, U.S. Dep't of Justice, Capital Punishment 1999, at 15 app. tbl.3. 


\section{BUFFALO CRIMINAL LAW REVIEW [Vol. 4:967}

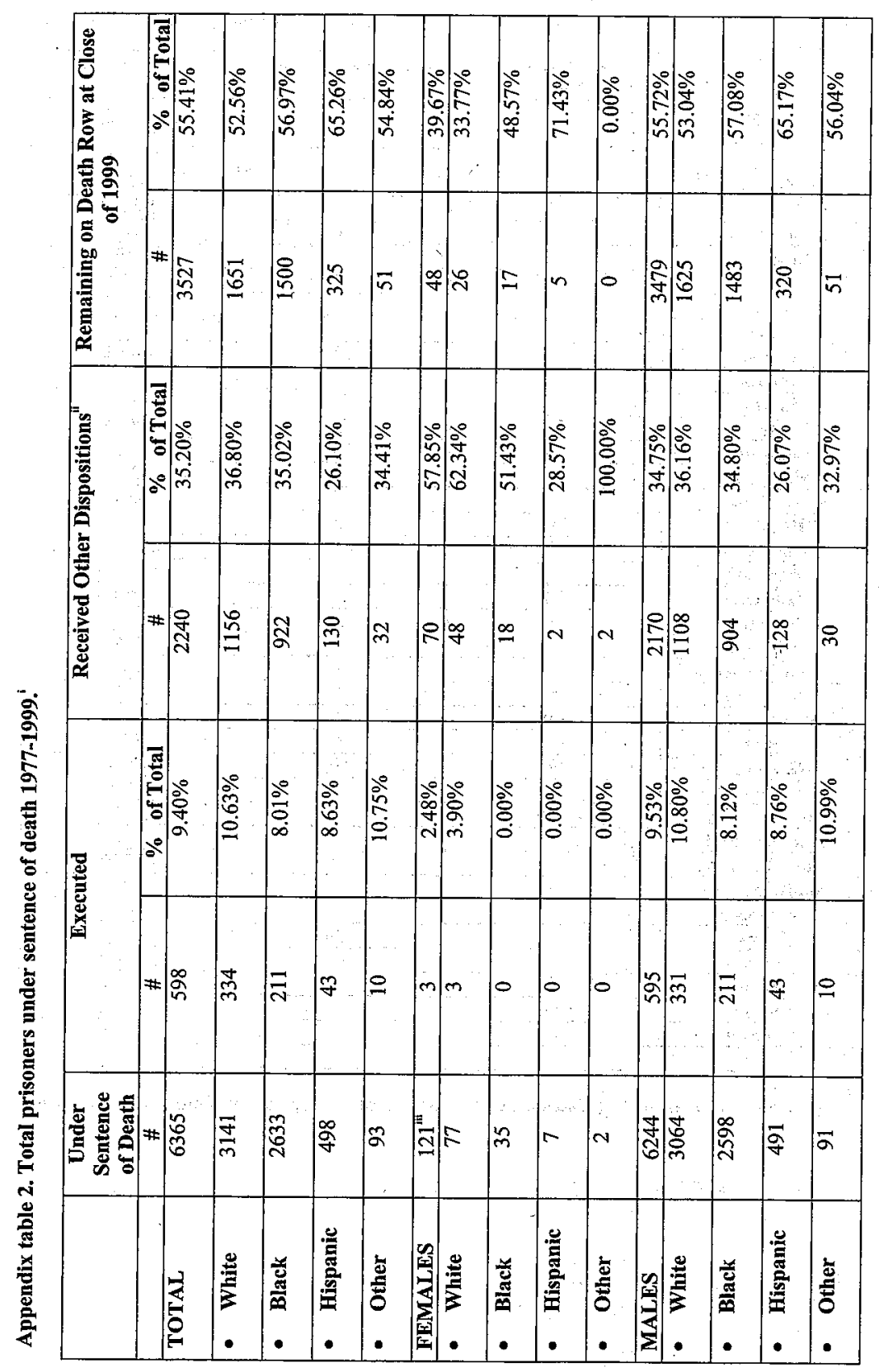




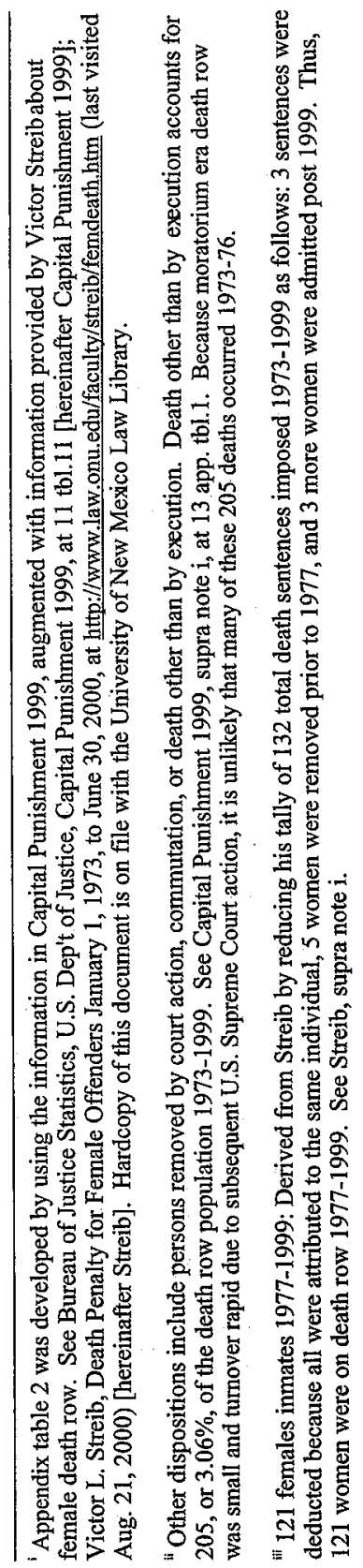

